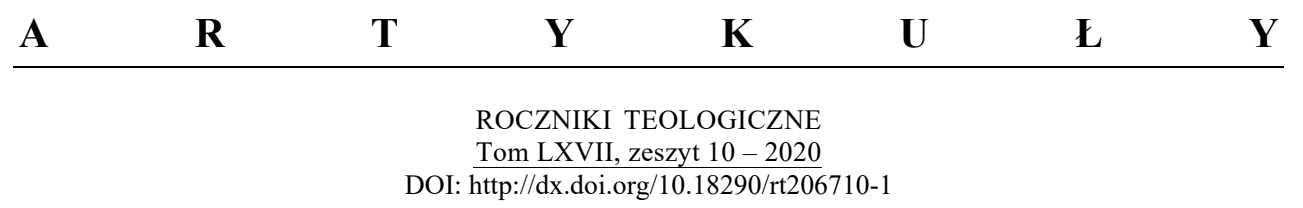

REV. PAWEŁ RABCZYŃSKI

\title{
CHRISTIAN FAMILY AS THE SOURCE AND PROPAGATOR OF VOCATIONAL CULTURE
}

\begin{abstract}
Building and transmitting vocational culture is among the primary duties of the Christian family. Vocational culture is composed of all actions supporting the work of awakening vocations to the priesthood and consecrated life. Characteristic elements of this culture are: deep religiosity, awareness of the Church mission and the correct vision of vocation. The family builds and transmits vocational culture through a conscious and consistent process of formation according to Christian values and models of behaviour. It thus answers the general call to love and holiness. It is aptly named the Home Church, the first seminary, and the treasury of vocations. The holiness of families is the main condition for the growth and maturation of authentic vocations, and the most appropriate answer to the modern crisis of vocational culture.
\end{abstract}

Key words: Christian family; cultural role of family; vocational culture; vocation to priesthood and consecrated life.

\section{INTRODUCTION}

Recent times have seen significant reflection on marriage and the family in Christianity. Modern difficulties, demands and challenges facing the lifelong union between a man and a woman have been analysed in the light of Divine Revelation. An undoubtable impulse for these reflections was Pope Francis's post-synodal apostolic exhortation Amoris laetitia on love in the family (Rome, 19 March 2016). The document resonated throughout the communities of the Roman Catholic Church, and even raised disputes among

Rev. PAWEŁ RABCZYŃSKI, doctor habilitus of theological sciences, adjunct professor at the Department of Fundamental, Dogmatic, and Moral Theology, Faculty of Theology, University of Warmia and Mazury in Olsztyn; e-mail: pawel.rabczynski@uwm.edu.pl; ORCID: https://orcid. org/0000-0002-8732-7019. 
theologians and pastors. ${ }^{1}$ Apart from a number of specifics, including those of significant doctrinal weight, it also contained observations imparting on the faithful the extent to which the world and the Church changed in the last few years, since John Paul II's apostolic exhortation Familiaris consortio (Rome, 22 November 1981) until the present day. A new look on the realities of marriage and family, stemming mainly from anthropological and cultural shifts, does not change the fact that the good of the family is of fundamental import for the future of the world and of the Church. That is because among the principal tasks of the family are building and propagation of culture, including the work of fostering vocations to the priesthood and religious life. Family is the first environment to care for vocations which come into being, discern their authenticity and accompany them. It is aptly called the Home Church (Ecclesia domestica), and the "first seminary." 2 The family, next to the parish community and specialised ecclesial structures such as seminaries and pastoral centres for priestly and monastic vocations, constitutes the foundation of vocational culture. ${ }^{3}$

The present paper adopts the definition of the family proposed by Leon Dyczewski: "The family is a communion of persons and a social institution based on love and free choice of a man and a woman joined in marriage who, in mutual responsibility, birth and raise the next generation, in a way which equips it to birth and raise a new generation in turn." ${ }^{, 4}$ Family thus understood is the basic environment for human birth and comprehensive development. ${ }^{5}$ Sadly, many attempts have been currently undertaken to redefine marriage and family. Western culture exhibits a dynamicity in the family structure and ever more commonly departs from its traditional model (the nuclear family) towards alternative family structures (the family as a group

\footnotetext{
${ }^{1}$ Rocco Buttiglione, Przyjacielska odpowiedź krytykom "Amoris Laetitia” [A Friendly Response to the Critics of "Amoris laetitia"] (Kraków: Wydawnictwo WAM, 2018); Giovanni/Fidalgo DEL Missier, Antonio GerARdo, Amoris laetitia jako ewangelia mitości i droga do przebycia [Amoris laetita as a Gospel of Love and a Road to be Travelled] (Kraków: Wydawnictwo Homo Dei, 2019).

${ }^{2}$ Zasady formacji kaptańskiej w Polsce [Rules of Priestly Formation in Poland] (Częstochowa, 1999), no. 29, p. 43.

${ }^{3}$ BeNEDICT XVI, "Kierownictwo duchowe, Rozważanie przed modlitwą Anioł Pański” [Spiritual Direction, A Meditation Before the Angelus Prayer], 15 January 2012, L'Osservatore Romano, Polish edition (2012), 3: 36; FrANCIS, Posynodal apostilic exhortation Evangelii gaudium (24 November 2013), no. 107; Congregation for the Clergy, The Gift of the Priestly Vocation, Ratio Fundamentalis Institutionis Sacerdotalis, (Vatican City: L'Osservatore Romano 2016), 14-15.

${ }^{4}$ Leon Dyczewski, Rodzina. Spoleczeństwo. Państwo [Family. Society. State] (Lublin: Towarzystwo Naukowe KUL, 1994), 27.

${ }^{5}$ Ibidem, 41-48.
} 
of relatives, in-laws, friends, and other persons gathered around a parent with a child, most commonly the mother). ${ }^{6}$

\section{VOCATIONAL CULTURE}

Vocational culture creates a proper spiritual climate which favours the discernment and acceptance of a vocation for priestly and consecrated life. ${ }^{7}$ It is a culture open to the gift of vocation, whose initiator and tutor is God himself. John Paul II explains that vocational culture springs from the culture of new life, which rests on gratitude, selflessness, generosity, and responsibility. The Pope stresses that this is a culture open to God, who safeguards the dignity of the human person and respect for both its body and spirit. ${ }^{8}$ The bishop of Rome also reminds us that mysterium vocationis belongs to the Church's nature and constitutes the main premise of its work. This is because Ecclesia is an "assembly," a gathering of people who have been called by God to form a congregation around Jesus Christ in the power of the Holy Spirit. ${ }^{9}$ God's New People is a new family of Jesus' apostles, a communion of those who do God's will. ${ }^{10}$ This is why the life and mission of the Church includes caring for new vocations to the priesthood and consecrated life, discerning them, and accompanying them. ${ }^{11}$ In this manner, Ecclesia is in service to the family. On the other hand, the Christian family builds the Church. In the family, a person, through birth and fostering, is introduced into the human community, but also, through holy sacraments and catechesis, is introduced ever deeper into God's new family - the Church. Marriage and family are the natural environment accomplishing the introduction of the human to the great family of the Church. Ecclesia finds its space in the family, thanks to which it enters human generations, and they enter the Church. ${ }^{12}$

\footnotetext{
${ }^{6}$ Tomasz SzLENDAK, Socjologia rodziny, Ewolucja, historia, zróżnicowanie [Sociology of Family. Evolution, History, Diversity] (Warszawa: Wydawnictwo Naukowe PWN, 2010), 94-115.

${ }^{7}$ Congregation for the Clergy, "The Gift of the Priestly Vocation," no. 14, p. 15.

${ }^{8}$ John PaUl II, Message for the XXX World Day of Prayer for Vocations 1993 (Castel Gandolfo, 8 September 1992), no. 2.

${ }^{9}$ Gerhard Lohfink, Czy Bóg potrzebuje Kościola? [Does God Need the Church?] (Poznań: W drodze, 2005), 329-355.

${ }^{10}$ Ibidem, 244-247.

${ }^{11}$ John PAUL II, Postsynodal apostolic exhortation Pastores dabo vobis (Rome, 25 March 1992), no. 34.

12 JoHn PAUl II, Apostolic exhortation Familiaris consortio (Rome, 22 November 1981), no. 15.
} 
Vocational culture is composed of all activities supporting the work of growing vocations to the priesthood and consecrated life, and especially: the formation of conscience, developing sensitivity to spiritual and moral values, propagation and defence of ideals of brotherhood, sanctity of life, social solidarity and legal order. These help people seek answers to the meaning of existence: to discover truth about themselves, the world and God; to understand that the Creator has a design, a plan, a specific life project for everyone. This plan is a proposal of realising natural gifts and charismata, which the given person has been endowed with for the good of their own, of society and of the Church community. Recognising and following one's vocation according to God's design allows a person to discover their own identity and happily proceed towards a unity with Him. ${ }^{13}$

The Christian vision of vocation emphasizes christoformity as the goal of human life. It is achieved with the help of the Holy Spirit, which aids one in imitating Jesus Christ and transforming one's entire life by His example (cf. Eph 4:13). He instructs Christians to love and serve God and brothers (cf. J 13:14-15). Pro-existence (being for others) is the deepest sense of every vocation, its specific form being vocation for priesthood and monastic life. ${ }^{14}$ Thus, Christian vocational culture consists in the conviction that "only in the mystery of the incarnate Word" - Jesus Christ - "does the mystery of man take on light." It is He who "fully reveals man to man himself and makes his supreme calling clear." ${ }^{15}$ Jesus is "the model of man." ${ }^{16}$ In Christ, a Christian learns the sense and aim of his own existence, he recognises his life as an undeserved gift, which one can realise in full dignity through self-sacrifice in the service of others. ${ }^{17}$

Vocational culture rests on higher spiritual, moral, and religious values; it is a culture which understands human life in terms of a gift and a mission,

${ }^{13}$ John PAUL II, Postsynodal apostolic exhortation Pastores dabo vobis, no. 35-37; JoHN PAUL II, Message for the XXX World Day of Prayer for Vocations 1993, no. 2; FRANCIS, Message for the LV World Day of Prayer for Vocations 2018 (Vatican, 3 December 2017); PonTIFICAL WORK FOR ECCleSiastical Vocations, New Vocations for a New Europe. "In verbo tuo." Final Document of the Congress on Vocations to the Priesthood and to Consecrated Life in Europe (Rome, 5-10 May 1997) (Poznań: Pallottinum, 1998), no. 13, pp. 21-23.

${ }^{14}$ John PaUl II, Postsynodal apostolic exhortation Pastores dabo vobis, no. 40.

15 Second Vatican Council, Pastoral Constitution on the Church in the Modern World Gaudium et spes (Rome, 7 December 1965), no. 22; JoHN PAUL II, Encyclical Redemptor hominis (Rome, 4 March 1979), no. 8.

${ }^{16}$ Pontifical Work for Ecclesiatical Vocations, New Vocations for a New Europe, no. 15, p. 32.

${ }^{17}$ John PaUl II, Message for the XXX World Day of Prayer for Vocations 1993, no. 2. 
a culture of life and of openness to new life in Christ. When understood in this way, it promotes and defends the ideals of life's sanctity, brotherhood among men, social solidarity and civil rights, while at the same time allowing contemporary people to find their identity and reacquire enduring values, such as love, friendship, prayer and contemplation. Accepted as one's own, fostered and constantly developed, these lead to a life testimony devoted to the highest and holiest spiritual and religious values, among which is also the gift of vocation to priestly and consecrated life. ${ }^{18}$

Currently, we see a crisis of vocational culture, or, to put it another way a proliferation of anti-vocational culture. ${ }^{19}$ This process is especially visible in North America and western Europe, but also increasingly in traditionally Catholic countries such as Poland. The causes of this are complex. Generally, blame is placed on a crisis of religious faith caused by encroaching ideas of secularism, consumerism, and religious indifference. The crisis of faith is closely connected with the crisis of culture which, devoid of higher values, also fails to transmit Christian values, and no longer secures continuity of tradition, becoming, in fact, an anti-culture, a "culture of death." Contemporary people, deprived of religious reference points in culture, uprooted from the presence of the sacred, lose their identity and sense of purpose in life. Steeped in the anthropology of the mundane, they no longer find answers to the burning questions of the goal and meaning of life. They reject the Church as a redeeming institution, and instead treat it as a peripheral element of a pluralistic society, called upon in life's specific moments as a peculiar religious backdrop. ${ }^{20}$

The crisis of vocational culture manifests itself in the lack of understanding of the sacramental structure of the Church and the person called to priesthood or consecrated life. Its symptoms are a formal withdrawal from the Church (e.g. acts of apostasy), withdrawals from religious practices, a decline in religious knowledge, a lack of faith-building and transmission in families, disappearance of traditional social structures of the Church and its social influence. The ubiquitous anti-vocational culture depreciates priestly

\footnotetext{
${ }^{18}$ Ibidem.

${ }^{19}$ Henryk Seweryniak, "Teologia powołania w świetle "In verbo tuo" [Theology of Vocation in the Light of In verbo tuo], in: WX-lecie 'In verbo tuo' - Nowe powolania dla nowej Euro$p y$ - refleksja teologiczna $i$ pastoralna [On the 10th Anniversary of In verbo tuo - New Vocations for a New Europe - a Theological and Pastoral Reflection] (Gniezno: Prymasowskie Wydawnictwo Gaudentinum, 2008), 16-21.

${ }^{20}$ Andrzej BronK, Zrozumieć świat wspótczesny [Understanding the Modern World] (Lublin: Towarzystwo Naukowe KUL, 1998), 179-202.
} 
and consecrated life, devalues pastoral service, and ridicules the daily existence of the called. ${ }^{21}$ This often involves the mass media through publicising and exaggerating the "sins of churchmen," which are, of course, worthy of condemnation and deserving of restitution.

The increasing vocational crisis must raise concern. Action is necessary to promote vocational culture primarily in the family environment. ${ }^{22}$ Sadly, even that is touched by phenomena linked with the "culture of death," such as divorce, abortion, euthanasia, genetic experimentation, so-called informal relationships, same-sex marriages and various addictions. The widespread occurrence of these destructive practices and their legal recognition requires the Christian family to build a culture inspired by religious convictions and ethical norms focused around Christian values. ${ }^{23}$

\section{BUILDING AND TRANSMISSION OF VOCATIONAL CULTURE IN THE FAMILY}

Vocation for the priesthood and consecrated life is born primarily in the communities of the family and the parish. The significance of the family is paramount in discovering a vocation, fostering it and accompanying the called person. It is responsible for supporting and strengthening candidates to the priesthood on each stage of their formation. ${ }^{24}$ That is why the family plays a fundamental role in building and transmitting vocational culture.

Culture possesses a clear personal and axiological character. The transmission of culture to subsequent generations is the main task of every human generation. Culture does not initiate in a person and in society all by itself. Building and transmission of culture is accomplished primarily in the family through formation. ${ }^{25}$ Formation is the shaping of a mature and responsible

${ }^{21}$ Gisbert Greshake, Być kapłanem dzisiaj [Being a Priest Today] (Poznań: W drodze, 2010), 5-11.

${ }^{22}$ Pontifical Work for Ecclesiatical Vocations, New Vocations for a New Europe, no. 13 , p. 22.

${ }^{23}$ Leon DyCZEWSKI, Rodzina twórca i przekazicielem kultury [Family as the Builder and Transmitter of Culture] (Lublin: Towarzystwo Naukowe KUL, 2003), 177-215.

${ }^{24}$ Francis, Postsynodal apostolic exhortation Amoris laetitia (Rome, 19 March 2016), no. 203; Congregation for the Clergy, "The Gift of the Priestly Vocation,” no. 148, p. 73.

${ }^{25}$ Stanisław KowalczyK, Filozofia kultury, Próba personalistycznego ujęcia problematyki [Philosophy of Culture. An Attempt at a Personalistic Take] (Lublin: Redakcja Wydawnictw KUL, 1996), 89-99, 115-120; L. DyCZEwsKi, Rodzina. Społeczeństwo. Państwo [Family. Society. State], 105-127. 
human personality. This process is only possible if directed by higher values, i.e. according to its accepted, qualitatively and hierarchically ordered value system. ${ }^{26}$

The culture-building role of the family is realised in many forms and ways. The family is a formative group which introduces the young generation to the cultural circles with which it is connected (e.g. national, societal, social-group, or religious culture). By building and transmitting its culture, the family is the natural and basic environment for its members to shape their system of values, norms, and models of behaviour. The family safeguards the continuation of national heritage. It infuses values and signs passed down through time with new interpretations and meanings. It must further be stressed that the family, being at the centre of social change, fills a vital role of selective regulator for cultural diffusion. It inculcates and adopts elements of outside environment which are acceptable to it, while others - unacceptable - it rejects, or even defends against, in order to preserve its own cultural identity. ${ }^{27}$

The close relationship between the family, formation and vocational culture cannot be overstated. The family, with its key role in the formation of young generations, not only transmits, but also - in appropriate social conditions - builds vocational culture. Through the formation of children and youth, it guards and passes on the values indispensable for the development of individuals, as well as the whole society. It is the fullest and richest school of humanity, in which a person experiences and learns selfless love, faithfulness, mutual respect, and defence of life. ${ }^{28}$ The family is called to proclaim life as the gift and charge from God. ${ }^{29}$ Thanks to family ties, children and youth discover the sense of selfless service, the value of sacrifice and unconditional surrender of oneself, ${ }^{30}$ they realise the potential of sainthood and love. ${ }^{31}$ Thus, the family - as Benedict XVI teaches - is the primor-

${ }^{26}$ S. KowALCZYK, Filozofia kultury [Philosophy of Culture], 117; Leon DyCZEWSKI, Kultura polska $w$ procesie przemian [Polish Culture in the Process of Change] (Lublin: Towarzystwo Naukowe KUL, 1995), 57-62.

${ }^{27}$ L. DYCZEWSKI, Rodzina twórca i przekazicielem kultury [Family as Builder and Transmitter of Culture], 38-41; L. DyCZEwSKI, Kultura polska $w$ procesie przemian [Polish culture in the Process of Change], 69-77.

${ }^{28}$ John PAUL II, Message for the XXXI World Day of Prayer for Vocations 1994 (Vatican, 26 December 1993), no. 1.

${ }^{29}$ JoHn PAUL II, Encyclical Evangelium vitae (Rome, 25 March 1995), no. 92.

${ }^{30}$ JoHn PAUl II, Postsynodal apostolic exhortation Pastores dabo vobis, no. 40.

${ }^{31}$ FRANCIS, Address at the International "Humanum" colloquium on The Complementarity of Man and Woman, Family based on a bond between a man and a woman is an anthropological fact (Vatican, 17 November 2014). 
dial cell of society, teaching the young generation human and Christian values $^{32}$ and imparting the truth that every vocation is born out of God's will and is a manifestation of His love. ${ }^{33}$

Among the primary duties of the Christian family is participation in the life and mission of the Church. It finds its deep rationale in the family members' consecration through baptism and in their charge involved in matrimony to serve the Church and society. The Christian family's share in the prophetic, priestly and kingly offices of Jesus Christ and of the Church is accomplished through marital and familial love. The salvific mission of the family is thus expressed in the gift of love and life. ${ }^{34}$ This is the way the family realises its calling to be "a community of sanctification in which one learns to live meekness, justice, mercy, chastity, peace, purity of heart." ${ }^{\prime 35}$ It becomes a Home Church, which is the living face of the mystery of the Church, a place of salvific acting of the living Jesus Christ. ${ }^{36}$ In this Church, rendered as if in miniature, parents are "witnesses of the faith and love of Christ," ${ }^{37}$ as well as "the first to communicate the faith to their children and to educate them;" 38 they are those who by the example of Christian living help them in choosing a way in life, and if a vocation is discovered for the priesthood or consecrated life, they foster and protect it. In seeing their parents' deeply lived bond with God, based on love, faithfulness, prayer, and obedience, the children, surrounded with care and love, open up to the calling to exclusive service to God and trustingly accept the gift of vocation. ${ }^{39}$ The family, animated by the spirit of faith, love, and piety, quick with religious life, is the privileged place where young people may discern their vocation and develop it. That is why it can be called, so to say, the first semi-

\footnotetext{
32 Benedict XVI, Address to members of the Regional Board of Lazio, the Municipal Council of Rome and the Province of Rome, Family teaches human and Christian values as well as solidarity (Vatican, 14 January 2011).

${ }^{33}$ Benedict XVI, Message for the XLIX World Day of Prayer for Vocations 2012 (Vatican, 18 November 2011).

${ }^{34}$ JOHN PAUL II, Apostolic exhortation Familiaris consortio, no. 50; FrANCIS, Address to participants in the Plenary Assembly of the Pontifical Council for the Family, In the family we learn to love and defend life (Vatican, 25 October 2013).

${ }^{35}$ JoHn PAUl II, Message for the XXXI World Day of Prayer for Vocations 1994, no. 1; JoHN PAUL II, Apostolic exhortation Familiaris consortio, no. 71.

${ }^{36}$ Second Vatican Council, Dogmatic Constitution on the Church Lumen gentium (Rome, 21 November 1964), no. 11.

${ }^{37}$ Ibidem, no. 35.

${ }^{38}$ Second Vatican Council, Decree on the Apostolate of the Laity Apostolicam actuositatem (Rome, 18 November 1965), no. 11.

${ }^{39}$ John PAUL II, Message for the XXXI World Day of Prayer for Vocations 1994, no. 1.
} 
nary and an irreplaceable treasury of vocations..$^{40}$ The Christian family is the first and most natural place where a person experiences evangelical holiness, including that flowing from the sacrament of the Holy Orders understood as a relationship with God, an imitation of Christ the poor, chaste, and meek, a boundless love for people. ${ }^{41}$ The family is the scene for discernment and acceptance of God's plan for one's own life. The atmosphere which exists in the family determines if that proposition is accepted with trust and gratitude. ${ }^{42}$ In the Message for the XXXI World Day of Prayer for Vocations, we read that it is the duty of Christian parents to prepare, develop, and protect the vocations which God inspires in their family. It is a very important and delicate task, accomplished through the enrichment of family life with spiritual, moral, and religious values, i.e. through building, transmitting, and deepening the family's vocational culture. Characteristic elements of this culture are: deep religiosity, awareness of the Church mission, and the correct vision of vocation. A necessary condition for the proper discharging of the duty to promote vocations is the placement of the person of Jesus Christ in the centre of family life, and making Him the authentic model for the family. The role that the Creator set out for the family as a communion must also be accepted and undertaken - that of being a conscious environment conducive to the development of vocations. ${ }^{43}$ Only then will the vocation of a son or a daughter to God's exclusive service be received as an undeserved gift offered by God, which must be answered with great magnanimity, show-

\footnotetext{
${ }^{40}$ Second Vatican Council, Decree on Priestly Training Optatam totius (28 October 1965), no. 2; JoHn PAUL II, Postsynodal apostolic exhortation Pastores dabo vobis, no. 40; JOHN PAUL II, Message for the XXIV World Day of Prayer for Vocations 1987 (Vatican, 11 February 1987), no. 2; Józef Augustyn, "Czym żyją alumni?" [What Fills the Lives of Alumni?], in: Romuald KoŚLA, (Ed.), Trudne przestrzenie formacji seminaryjnej [Difficult Areas in Seminary Work], part 2, 49. Ogólnopolska Konferencja Rektorów Wyższych Seminariów Duchownych Diecezjalnych i Zakonnych [National Polish Conference of Rectors of Higher Diocesan and Monastic Seminaries] (Łódź-Łagiewniki, 2-5 września 2013) (Kraków: Unum, 2014), 82-83.

${ }^{41}$ John PAUL II, Postsynodal apostolic exhortation Pastores dabo vobis, no. 33.

${ }^{42}$ FRANCIS, Address during a prayer vigil for families, Family as a light in the dark world (Vatican, 3 October 2015).

43 John Paul II, Message for the XXXI World Day of Prayer for Vocations 1994, no 2; Zasady formacji kapłańskiej w Polsce [Rules of Priestly Formation in Poland], no. 29, pp. 43-44; Aleksander RADECKI, "Towarzyszenie młodym w odkrywaniu i realizacji powołania w rodzinie" [Accompanying the Young in the Discovery and Realisation of Vocation in the Family], in: Błażej STRóżYCKI (Ed.), Krajowe Duszpasterstwo Powołań, Towarzyszenie młodym w odkrywaniu powolania życiowego, Krajowa Kongregacja Odpowiedzialnych za Duszpasterstwo Powolań [National Pastoral Care of Vocations, Accompanying the Young in Discovering Life Vocation, National Congregation of Those Responsible for Pastoral Care of Vocations] (Jasna Góra, 20-22 October 2006) (Poznań, 2007), 21-35.
} 
ing to children the value of vocation to priesthood and consecrated life, and the accompanying joy of devoting oneself to God in complete and unconditional freedom. ${ }^{44}$

Pope Francis emphasizes that parents fill their role in the work of awakening vocations by showing their children the calling to completely surrender to God not as a limitation of human freedom or as a religious coercion, but as an initiative filled with love, which widens the territory of freedom; as participation in God's own project. A vocation is an invitation to follow Jesus along the way He himself has prepared for our happiness and for the good of the people He sends us to. That is why it must be shown as an engaging and fascinating decision to become a partner to Christ, often in difficult social and cultural conditions. In spite of the hardships involved in the vocation to the priesthood and consecrated life, the example of one's life must show that there is no greater joy than to wager one's life for the Lord. ${ }^{45}$ This calling is especially urgent nowadays, as young people succumb to lassitude in fulfilling religious practices and treat them as a mere obligation. The family is responsible for awakening in the youth an evangelical zeal to imitate Jesus and to discover the timeliness of His teaching, which is the answer to all the yearnings of the human heart. ${ }^{46}$

Building vocational culture is one of the most important aspects of a Christian family's mission, since by receiving the grace of bringing up their children, so often asked for in prayer, the spouses discover the fertility and richness of marital love, both in the bodily and spiritual aspect. Parents who generously open up to the gift of their son's or daughter's vocation to God's exclusive service and accept it gladly, receive thereby a confirmation of the spiritual fertility of their union. Marital love is thus enriched with love lived in celibacy and virginity for the Kingdom of God. ${ }^{47}$ Thanks to a vocation of a child to the priesthood or consecrated life, parents may participate even deeper in God's plan of salvation for people and the world. A vocation is a special gift for the family and simultaneously from the family. ${ }^{48}$

${ }^{44}$ John PAUL II, Message for the XXXI World Day of Prayer for Vocations 1994, no. 3.

${ }^{45}$ Francis, Message for the LVI World Day of Prayer for Vocations 2019 (Vatican, 31 January 2019).

${ }^{46}$ Francis, Message for the LIV World Day of Prayer for Vocations 2017 (Vatican, 27 November 2016).

47 John PAUL II, Message for the XXXI World Day of Prayer for Vocations 1994, no. 3.

48 John PAUL II, Message for the XXIV World Day of Prayer for Vocations 1987 (Vatican, 11 February 1987), no. 2; BENEDICT XVI, Message for the XLVI World Day of Prayer for Vocations 2009 (Vatican, 20 January 2009). 


\section{CONCLUSIONS}

The Christian family fulfils an important mission in the difficult task of raising the new generations. The young are the future and the hope of the society and of the Church. In spite of deep changes which have recently impacted the institution of marriage and family, in spite of ubiquitous materialism, consumerism, hedonism, and secularisation, it still remains the fullest and richest school of humanity, and a primary nurturing environment, where the values and norms of conduct are passed on. ${ }^{49}$ The strength and endurance of Christian families is the main condition for the growth and maturing of holy vocations to the priesthood and consecrated life, and the most appropriate answer to the modern crisis of vocational culture.$^{50}$ No community or social group can replace the family in its function of builder and transmitter of this culture. In the work of awakening vocations, the family plays the first and fundamental role. It is the natural seminary for the seeds of vocation. ${ }^{51}$ Building vocational culture is vitally dependent on the spiritual and moral condition of families. Personal holiness of the spouses and parents, lived in selfless and fertile love, the harmony of daily life, openness to others, and participation in the life of Church community constitute the best soil, on which the offer to follow Christ can be received, and the vocation itself can flourish. A flourishing of vocational culture is a sign of vitality of the spouses' faith and love, and a testimony of Christian families' moral health.

\section{BIBLIOGRAPHY}

Augustyn, Józef. “Czym żyją alumni?” [What Fills the Lives of Alumni?], in: Romuald KośLA, (Ed.), Trudne przestrzenie formacji seminaryjnej [Difficult Areas in Seminary Work], part 2. Ogólnopolska Konferencja Rektorów Wyższych Seminariów Duchownych Diecezjalnych i Zakonnych [National Polish Conference of Rectors of Higher Diocesan and Monastic Seminaries] (Łódź-Łagiewniki, 2-5 września 2013), s. 77-85. Kraków: Unum, 2014.

BENEDICT XVI. "Kierownictwo duchowe, Rozważanie przed modlitwą Anioł Pański" [Spiritual Direction, A Meditation Before the Angelus Prayer], 15 January 2012, L'Osservatore Romano, Polish edition (2012), 3.

BENEDict XVI. Address to members of the Regional Board of Lazio, the Municipal Council of Rome and the Province of Rome, Family teaches human and Christian values as well as solidarity (Vatican, 14 January 2011).

49 John PAUL II, Postsynodal apostolic exhortation Pastores dabo vobis, no. 7; Francis, Apostolic exhortation Evangelii gaudium, no. 61-67.

${ }^{50}$ John PAUL II, Message for the XXXI World Day of Prayer for Vocations 1994, no. 2.

${ }^{51}$ Ibidem, no. 3. 
Benedict XVI. Message for the XLIX World Day of Prayer for Vocations 2012 (Vatican, 18 November 2011).

Benedict XVI. Message for the XLVI World Day of Prayer for Vocations 2009 (Vatican, 20 January 2009).

BRONK, Andrzej. Zrozumieć świat współczesny [Understanding the Modern World], 179-202. Lublin: Towarzystwo Naukowe KUL, 1998.

Buttiglione, Rocco. Przyjacielska odpowiedź krytykom “Amoris Laetitia” [A Friendly Response to the Critics of "Amoris laetitia"]. Kraków: Wydawnictwo WAM, 2018.

COngregation for the Clergy. The Gift of the Priestly Vocation, Ratio Fundamentalis Institutionis Sacerdotalis. Vatican City: L’Osservatore Romano, 2016.

DYCZEWSKI, Leon. Kultura polska w procesie przemian [Polish Culture in the Process of Change]. Lublin: Towarzystwo Naukowe KUL, 1995.

DYCZEWSKI, Leon. Rodzina twórca i przekazicielem kultury [Family as the Builder and Transmitter of Culture]. Lublin: Towarzystwo Naukowe KUL, 2003.

Dyczewski, Leon. Rodzina. Spoleczeństwo. Państwo [Family. Society. State]. Lublin: Towarzystwo Naukowe KUL, 1994.

Francis, Posynodal apostilic exhortation Evangelii gaudium (24 November 2013). London: Catholic Truth Society, 2013.

FRANCIS. Address at the International "Humanum" colloquium on The Complementarity of Man and Woman, Family based on a bond between a man and a woman is an anthropological fact (Vatican, 17 November 2014).

FRANCIS. Address during a prayer vigil for families, Family as a light in the dark world (Vatican, 3 October 2015).

FRANCIS. Address to participants in the Plenary Assembly of the Pontifical Council for the Fami$l y$, In the family we learn to love and defend life (Vatican, 25 October 2013).

Francis. Message for the LIV World Day of Prayer for Vocations 2017 (Vatican, 27 November 2016).

FrANCIS. Message for the LV World Day of Prayer for Vocations 2018 (Vatican, 3 December 2017).

FrANCIS. Message for the LVI World Day of Prayer for Vocations 2019 (Vatican, 31 January 2019).

FrANCIS. Postsynodal apostolic exhortation Amoris laetitia (Rome, 19 March 2016). London: Catholic Truth Society, 2016.

Greshake, Gisbert. Być kapłanem dzisiaj [Being a Priest Today]. Poznań: W drodze, 2010.

John PAUl II. Apostolic exhortation Familiaris consortio (Rome, 22 November 1981). London: Catholic Truth Society, 1981.

John PAUL II. Encyclical Evangelium vitae (Rome, 25 March 1995). London: Catholic Truth Society, 1995.

John PaUl II. Encyclical Redemptor hominis (Rome, 4 March 1979). London: Catholic Truth Society, 2002.

John Paul II. Message for the XXIV World Day of Prayer for Vocations 1987 (Vatican, 11 February 1987).

John Paul II. Message for the XXX World Day of Prayer for Vocations 1993 (Castel Gandolfo, 8 September 1992). 
JoHn PaUL II. Message for the XXXI World Day of Prayer for Vocations 1994 (Vatican, 26 December 1993).

John PaUl II. Postsynodal apostolic exhortation Pastores dabo vobis (Rome, 25 March 1992). London: Catholic Truth Society, 1992.

Kowalczyk, Stanisław. Filozofia kultury, Próba personalistycznego ujęcia problematyki [Philosophy of Culture. An Attempt at a Personalistic Take]. Lublin: Redakcja Wydawnictwo KUL, 1996.

Lohfink, Gerhard. Czy Bóg potrzebuje Kościoła? [Does God Need the Church?]. Poznań: W drodze, 2005.

Missier, Giovanni/Fidalgo DEL, Antonio GeRARDo. Amoris laetitia jako ewangelia miłości i droga do przebycia [Amoris laetita as a Gospel of Love and a Road to be Travelled]. Kraków: Homo Dei, 2019.

Pontifical Work for ECClesiastical Vocations. New Vocations for a New Europe. "In verbo tuo." Final Document of the Congress on Vocations to the Priesthood and to Consecrated Life in Europe (Rome, 5-10 May 1997). Poznań: Pallottinum, 1998.

RADECKI, Aleksander. "Towarzyszenie młodym w odkrywaniu i realizacji powołania w rodzinie" [Accompanying the Young in the Discovery and Realisation of Vocation in the Family], in: Błażej STRÓżYCKI (Ed.), Krajowe Duszpasterstwo Powolań, Towarzyszenie młodym w odkrywaniu powołania życiowego, Krajowa Kongregacja Odpowiedzialnych za Duszpasterstwo Powotan' [National Pastoral Care of Vocations, Accompanying the Young in Discovering Life Vocation, National Congregation of Those Responsible for Pastoral Care of Vocations] (Jasna Góra, 20-22 October 2006), 21-35. Poznań: Krajowe Duszpasterstwo Powołań, 2007.

Second Vatican Council. Decree on Priestly Training Optatam totius (28 October 1965). Boston: Pauline Books and Media, 1966.

Second Vatican Council. Decree on the Apostolate of the Laity Apostolicam actuositatem (Rome, 18 November 1965). Boston: Pauline Books and Media, 1965.

Second Vatican Council. Dogmatic Constitution on the Church Lumen gentium (Rome, 21 November 1964). Boston: Pauline Books and Media, 2000.

Second Vatican Council. Pastoral Constitution on the Church in the Modern World Gaudium et spes (Rome, 7 December 1965). Boston: Pauline Books and Media, 1966.

SEWERYNIAK, Henryk."Teologia powołania w świetle "In verbo tuo" [Theology of Vocation in the Light of 'In verbo tuo']. In: $W$ X-lecie 'In verbo tuo' - Nowe powolania dla nowej Europy - refleksja teologiczna i pastoralna [On the 10th Anniversary of 'In verbo tuo' - New Vocations for a New Europe - a Theological and Pastoral Reflection], 9-21. Gniezno: Prymasowskie Wydawnictwo Gaudentinum, 2008.

SzLENDAK, Tomasz. Socjologia rodziny, Ewolucja, historia, zróżnicowanie [Sociology of Family. Evolution, History, Diversity]. Warszawa: Wydawnictwo Naukowe PWN, 2010.

Zasady formacji kaptańskiej w Polsce [Rules of Priestly Formation in Poland]. Częstochowa: Biblioteka "Niedzieli," 1999. 


\title{
RODZINA CHRZEŚCIJAŃSKA ŹRÓDŁEM I PRZEKAZICIELEM KULTURY POWOŁANIOWEJ
}

\begin{abstract}
STRESZCZENIE
Budowanie i przekazywanie kultury powołania należy do podstawowych obowiązków rodziny chrześcijańskiej. Kultura powołaniowa obejmuje wszelkie działania wspierające dzieło przebudzenia powołań do kapłaństwa i życia konsekrowanego. Charakterystycznymi elementami tej kultury są: głęboka religijność, świadomość misji Kościoła i właściwa wizja powołania. Rodzina buduje i przekazuje kulturę powołania poprzez świadomy i konsekwentny proces formacji zgodnie z chrześcijańskimi wartościami i wzorcami zachowań. W ten sposób odpowiada na powszechne powołanie do miłości i świętości. Jest trafnie nazywana Domowym Kościołem, pierwszym seminarium i skarbnica powołań. Świętość rodzin jest głównym warunkiem wzrostu i dojrzewania autentycznych powołań oraz najwłaściwszą odpowiedzią na współczesny kryzys kultury powołaniowej.
\end{abstract}

Słowa kluczowe: rodzina chrześcijańska; kulturotwórcza funkcja rodziny; kultura powołaniowa; powołanie do kapłaństwa i życia konsekrowanego. 